\title{
Pengaruh Mindfulness terhadap Stres Akademik pada Siswa SMAN X Cianjur di Masa Pandemi COVID-19
}

\author{
Dianita Maulinda*, Makmuroh Sri Rahayu \\ Indonesia. \\ *dianitamaulinda33@gmail.com, makmurohsrir@yahoo.com
}

Prodi Ilmu Psikologi, Fakultas Psikologi, Universitas Islam Bandung,

\begin{abstract}
The transition of learning and teaching methods occurred in Indonesia during the Covid19 pandemic. This situation makes students have to be able to make adjustments to different situations, however, students still have demands, in addition with the pandemic situation that makes students stressed. Stress experienced in education is called academic stress. Many things can be done by students to overcone with stress, one of them is with mindfulness. The aim of this research was to determine the effect of mindfulness on academic stress in SMAN X Cianjur students during the Covid-19 pandemic. The research sample amounted to 298 students with a sampling technique was using proportionate stratified random sampling. The measuring instrument used is Child and Adolescent Mindfulness Measure for mindfulness, and Educational Stress Scale for Adolescents for academic stress, both measuring instruments have been translated into Bahasa. This research uses a causal quantitative approach. The data analysis technique was carried out using simple linear regression with the results of the regression coefficient being negative and based on the results of the determination test, it was obtained Rsquare: $47.2 \%$. The results show that if students have low mindfulness, it will cause high academic stress.
\end{abstract}

Keywords: Academic Stress, High School Student, Mindfulness.

\begin{abstract}
Abstrak. Transisi metode belajar dan mengajar terjadi di Indonesia selama pandemi Covid-19. Situasi ini membuat pelajar harus bisa melakukan penyesuaian terhadap situasi yang berbeda, namun demikian siswa masih memiliki tuntutan, ditambah dengan situasi pandemi yang membuat siswa menjadi stres. Stres yang dialami dalam pendidikan disebut stres akademik. Banyak hal yang dapat dilakukan oleh siswa untuk mengatasi stres tersebut, salah satunya dengan mindfulness. Tujuan penelitian ini adalah untuk mengetahui pengaruh mindfulness terhadap stres akademik pada siswa SMAN X Cianjur di masa pandemi Covid-19. Sampel penelitian berjumlah 298 siswa dengan teknik sampling menggunakan proportionate stratified random sampling. Alat ukur yang digunakan adalah Child and Adolescent Mindfulness Measure untuk mindfulness, dan Educational Stress Scale for Adolescents untuk stres akademik, kedua alat ukur telah diterjemahkan kedalam bahasa Indonesia. Penelitian ini menggunakan pendekatan kuantitatif kausalitas. Teknik analisis data dilakukan dengan menggunakan regresi linear sederhana dengan hasil koefesien regresi bernilai negatif dan berdasarkan hasil uji determinasi didapatkan Rsquare: $47.2 \%$. Hasil menunjukkan bahwa jika siswa memiliki mindfulness yang rendah, maka akan menyebabkan stres akademik yang tinggi.
\end{abstract}

Kata Kunci: Mindfulness, Stres Akademik, Siswa SMA. 


\section{A. Pendahuluan}

Pada saat ini kita telah menghadapi pandemi virus Covid-19 selama satu tahun lamanya, bahkan terdapat berita bahwa mutasi virus corona yang baru sudah masuk di Indonesia (Kompas.com, 2021), maka dari itu tanda-tanda berkurangnya virus Covid-19 masih belum terlihat. Sehingga dengan keadaan situasi pandemi tersebut, pemerintah di Indonesia masih menerapkan sistem pembelajaran secara daring yang diberlakukan sebagai bentuk pencegahan menularnya virus Covid-19. Pandemi Covid-19 memiliki karakteristik yang dapat memicu munculnya stres seperti ambiguitas, ketidakpastian, isolasi dari lingkungan sosial, kehilangan kendali, serta memunculkan rasa khawatir, hal-hal tersebut dapat menyebabkan atau dapat meningkatkan stres, termasuk gejala internalisasi dan emosional (Reger, et al, 2020).

Pandemi Covid-19 jauh lebih besar berdampak pada usia remaja dibandingkan dengan orang dewasa, karena mereka lebih rentan terhadap efek negatif stres (Zhang, et al, 2020). Hal tersebut dikarenakan motivasi perkembangan dan perubahan hormonal membuat remaja sangat terbiasa dengan kelompok teman sebaya, maka pada usia remaja sulit untuk hanya berdiam diri di rumah (Zhang, et al, 2020). Dalam penelitian ini peneliti memfokuskan pada jenjang Sekolah Menengah Atas. Menurut Santrock (2011), masa sekolah menengah berada pada periode remaja, yaitu sebuah periode di mana segala sesuatu mengalami perubahan atau transisi, baik dari segi perubahan sosial, kegiatan di sekolah yang berbeda, kehidupan keluarga, serta kehidupan pribadi. Segala perubahan yang berlangsung membuat individu yang berada di tingkat pendidikan tersebut merasa mudah tertekan (Ananda dan Apsari, 2020).

Dalam keterikatan, remaja mempercayai teman sebayanya lebih dari orang tua mereka, sehingga membuat mereka lebih dekat dengan teman sebaya dibandingkan orang tua mereka (Sarmin, 2017), namun pada saat ini hubungan dengan teman di sekolah maupun lingkungan rumah menjadi sangat terbatas karena adanya anjuran untuk menghindari aktivitas di luar rumah serta kegiatan pembelajaran di sekolah pun berubah menjadi daring.

Terjadinya perubahan sistem pembelajaran menjadi daring berpotensi mengancam kesehatan mental remaja secara signifikan (Fegert, et al, 2020). Hal tersebut terjadi, karena kehidupan para remaja ikut terpengaruh seiring dengan dilakukannya berbagai kebijakan untuk mengurangi dampak dari pandemi Covid-19 (Ananda dan Apsari, 2020). Dengan adanya pembatasan kegiatan sosial mengakibatkan remaja memiliki kegiatan sehari-hari yang terbatas, seperti tidak bisa bermain karena tidak diperkenankan melakukan kegiatan yang bersifat kelompok (Fegert et al, 2020). Sehingga terdapat individu yang sampai terganggu psikologisnya, menjadi stres dan kesulitan untuk mengikuti kegiatan pembelajaran (Rahardjo et al, 2020).

Stres yang dialami oleh siswa bukanlah suatu hal yang baru terjadi. Seperti hasil survey penelitian Metrowest Adolescent Health pada tahun 2016, hasil menunjukan bahwa stres yang dialami siswa SMA pada tahun 2012 meningkat dari 29\% menjadi 36\% pada tahun 2016 (Jim, 2017). Menurut pendapat Misra dan Mc Kean, mengungkapkan bahwa stres pada siswa dipengaruhi oleh keinginan pribadi yang tidak sejalan dengan kondisi lingkungan belajarnya, seperti kurikulum di sekolah yang padat, pendidikan yang berlanjut, mengambil suatu keputusan, penjurusan, guru dan lingkungan pertemanan yang berbeda karakter (Qurrotu'ain, 2019). Sehingga kondisi lingkungan belajar yang berubah serta tidak sesuai harapan siswa pada saat ini dapat juga menjadi salah satu penyebab stres semakin tinggi.

Kemudian salah satu penyebab meningkatnya stres remaja pada masa pandemi saat ini adalah karena mereka mengalami kesulitan saat harus belajar di rumah akibat pandemi. Dari survei yang dilakukan KPAI, sebanyak 79,9\% anak berpendapat bahwa interaksi berkurang, dan guru hanya memberikan tugas berat saja sehingga anak mengalami peningkatan stres dan 20,1\% yang menganggap adanya interaksi dalam proses pembelajaran (liputan6.com).

Stres yang terjadi dan dialami dalam lingkup pendidikan disebut dengan stres akademik (Lazarus dan Folkman, 1984 dalam Hidayat dan Fourianalistyawati, 2017). Stres akademik ini dapat disebabkan oleh tekanan akademik yang meningkat, sistem pendidikan, serta tugas yang berlebihan sehingga dapat mempengaruhi proses berpikir, emosi, fisik, dan perilaku individu tersebut (Azmy, et al, 2017 dalam Barseli, et al, 2020). Maka dari itu sistem pendidikan atau metode pengajaran yang berubah menjadi daring serta tugas-tugas yang 
diberikan oleh guru secara berlebih dapat memunculkan stres akademik yang lebih tinggi. Perubahan mendadak serta tekanan yang dihadapi siswa baik secara internal maupun eksternal dapat memicu emosi negatif, termasuk stres. Selain itu, proses pembelajaran dengan media online lebih melelahkan serta membosankan akibat menurunnya interaksi langsung, baik dengan guru maupun dengan teman yang memberikan dukungan sosial yang berujung pada frustasi serta stres (Muslim, 2020).

Fenomena stres akademik pada masa pandemi Covid-19 juga terjadi disalah satu SMA di Cianjur. Perubahan sistem pembelajaran juga dialami di sekolah ini. Pada SMAN X ini memiliki sistem program literasi yang baik dimana siswa belajar untuk sering membaca dan menulis. Akan tetapi dengan keadaan pandemi saat ini, dimana sekolah harus melakukan pembelajaran jarak jauh membuat adanya perubahan dalam sistem program pembelajaran. Pada saat pembelajaran jarak jauh diberlakukannya jadwal mingguan, yaitu terdapat satu minggu untuk jadwal kegiatan literasi, satu minggu untuk jadwal kegiatan penugasan, dan satu minggu untuk jadwal kegiatan materi. Pada minggu jadwal literasi guru-guru memberikan bahan untuk dibaca atau memberikan tontonan seperti video dari youtube.

Didapatkan dari hasil wawancara kepada siswa, siswa berpendapat bahwa kegiatan literasi dengan keadaan pembelajaran jarak jauh tidak efektif dibandingkan dengan kegiatan pada saat sekolah tatap muka. Hal itu dikarenakan siswa merasa kurangnya pengawasan secara ketat, tidak seperti sebelumnya saat sekolah diadakan secara tatap muka. Hal tersebut mengakibatkan beberapa siswa menjadi ada yang tidak mengerjakan kegiatan literasi tersebut, dan hal itu juga yang menyebabkan siswa merasa kurangnya pemahaman yang didapatkan serta merasa kebingungan pada materi pembelajaran yang guru berikan dikarenakan siswa merasa terkadang kurangnya mendapatkan penjelasan dari guru dan merasa tidak bebas untuk mengemukakan pendapat serta pertanyaan karena terbatasi oleh keadaan pembelajaran jarak jauh. Sehingga siswa merasa kegiatan menjadi kurang efektif pada saat keadaan pembelajaran jarak jauh.

Kemudian dari hasil wawancara tambahan peneliti pada siswa-siswi di sekolah ini, didapatkan bahwa beberapa siswa mengatakan jika tugas yang diberikan ketika pembelajaran jarak jauh menjadi suatu tekanan bagi mereka. Mereka juga mengatakan bahwa pembelajaran jarak jauh dirasa kurang efektif dibandingkan dengan pembelajaran tatap muka karena ketika sekolah diadakan secara tatap muka seperti biasa, maka materi yang disampaikan lebih mudah untuk dipahami, tidak bisanya berinteraksi dengan guru secara langsung yang terkadang membuat mereka merasa sulit ketika mempelajari materi yang diberikan. Dari wawancara tersebut juga terdapat tanggapan bahwa dengan sekolah seperti biasa atau secara tatap muka membuat belajar lebih fokus lagi dibandingkan dengan pembelajaran jarak jauh karena ketika pembelajaran jarak jauh siswa merasa jenuh dan bosan, mereka juga merasa dengan sekolah secara tatap muka membuat lebih banyak bersosialisasi dibandingkan dengan pembelajaran jarak jauh, dengan sekolah secara tatap muka juga membuat interaksi dengan guru atau teman di sekolah pun menjadi terasa lebih mudah.

Situasi-situasi serta keadaan tersebut membuat siswa menjadi lebih tertekan, sehingga membuat mereka merasa lebih cemas, khawatir, sulit untuk bisa fokus ketika belajar, bahkan menjadi sulit untuk tenang sehingga meningkatkan stres akademik. Ketika seorang siswa dalam keadaan yang mindful, mereka dapat bekerja pada sifat pencapaian belajar yang lebih fokus, lebih terlibat dan menjadi lebih berdamai dengan keadaan yang tidak menyenangkan dan menimbulkan stres (Napoli, et al, 2005). Menurut Chen (2009) munculnya stres itu tergantung dari adanya stresor, dalam bidang akademik sendiri, tuntutan, tanggung jawab, serta tekanan yang berasal dari aktivitas akademik disebut dengan stresor akademik (Taufik, et al, 2013).

Mindfulness itu sendiri merupakan suatu kondisi di mana individu memberikan perhatiannya secara sengaja sebagai upaya untuk menyadari kondisi individu tersebut dan tidak memberikan penilaian apapun pada kondisi tersebut (Singh, et al, 2006). Menurut Gardner dan Grose (2015) mengatakan bahwa mindfulness merupakan cara pencegahan tumbuhnya stres, konflik dan kekacauan dalam lingkup pendidikan. Mindfulness itu sendiri yaitu keadaan dengan penuh kesadaran dan perhatian terhadap kejadian pada masa sekarang 
(Brown dan Ryan, 2003 dalam Waskito, et al, 2018).

Jika siswa tidak sepenuhnya menerapkan mindfulness, siswa dapat mengalami masalah dalam melihat, mengamati, serta menilai permasalahan yang mereka hadapi. Kabat-Zinn (2005) menjelaskan bahwa hal tersebut dapat membuat seseorang kesulitan dalam mengelola berbagai peristiwa yang dialami, sehingga dapat menyebabkan tekanan akademik yang tinggi. Kemudian jika seseorang dalam kondisi mindfulness, dia akan benar-benar ingin mengelola berbagai faktor tekanan dengan baik, tetapi jika seseorang memiliki mindfulness yang rendah, dia biasanya akan merasa tidak mampu mengelola tekanan sehingga memunculkan stres (Kabat-Zinn, 2005).

Berdasarkan fenomena yang telah dipaparkan, pengertian stres akademik, pengertian mindfulness, serta penelitian-penelitian hubungan mindfulness dan stres, seperti penelitian yang dilakukan oleh Araas (2008) dimana penelitiannya menunjukan hasil mindfulness memiliki hubungan yang negatif terhadap stres (Hidayat dan Fourianalistyawati, 2017). Selain itu hasil dari penelitian oleh Elizabeth (2017) yaitu menghasilkan peringkat midfulness dan stres siswa berkorelasi negatif. Oleh karena itu, hipotesis bahwa mindfulness dan stres berkorelasi terbalik diverifikasi dalam penelitian tersebut. Ditambah masih kurangnya penelitian yang membahas dengan subjek remaja dan khususnya dengan keadaan pandemi Covid-19 ini. Oleh karena itu peneliti tertarik untuk meneliti lebih lanjut mengenai pengaruh mindfulness terhadap stres akademik pada siswa SMAN X Cianjur seta dikaitkan juga dengan keadaan masa pandemi Covid-19.

\section{B. Metodologi Penelitian}

\section{Landasan Teori}

Mindfulness biasanya didefinisikan untuk memasukkan perhatian penuh seseorang pada pengalaman yang terjadi pada saat ini, dengan cara yang tidak menghakimi atau menerima (Brown dan Ryan, 2003 dalam Baer, et al, 2006). Mindfulness merupakan peningkatan kesadaran penuh dengan berfokus pada pengalaman saat ini serta penerimaan tanpa memberikan penilaian (Baer, et al, 2006). Berikut aspek-aspek dari mindfulness menurut Baer, Smith dan Greco (2011) khususnya pada remaja, sesuai dengan alat ukur yang digunakan, yakni acting with awareness yaitu mengacu pada kesadaran yang berpusat pada saat ini. Seseorang bertindak dengan sengaja secara sadar dalam menyelesaikan aktivitas mereka dengan berkonsentrasi serta perhatiannya tidak terbagi. Serta accepting without judgement yaitu menerima tanpa menghakimi cenderung mengambil perbuatan non-evaluatif. Ketika seorang siswa dalam keadaan yang mindful, mereka dapat bekerja pada sifat pencapaian belajar yang lebih fokus, lebih terlibat dan menjadi lebih berdamai dengan keadaan yang tidak menyenangkan dan menimbulkan stres (Napoli, et al, 2005).

Stres akademik menurut Barseli, et al, ialah tekanan yang disebabkan adanya perspektif subjektif terhadap suatu kondisi akademik (Barseli, et al, 2017). Sedangkan stres akademik didefinisikan oleh Ang dan Huan yaitu sebagai pandangan seseorang tentang harapan diri dan harapan guru atau orangtua tentang masalah akademik (Ang dan Huan, 2006). Menurut Sun, et al. (2011) stres akademik sebagai tekanan secara psikologis yang dirasakan oleh individu, dimana tekanan tersebut yang lebih besar berasal dari permasalahan akademik daripada peristiwa kehidupan.

Terdapat lima aspek untuk mengukur stres akademik menurut Sun, Dunne, dan Hou (2011), yakni pressure from study meliputi perasaan tertekan yang dialami oleh individu yang diakibatkan oleh beban studi di sekolah mereka, workload merupakan aspek stres akdemik dimana individu menganggap terlalu banyaknya beban tugas yang dirasakan, worry about grades dimana siswa merasakan cemas atau gelisah pada nilai-nilai yang didapatnya saat sekolah serta memandang nilai tersebut merupakan suatu hal yang penting bagi dirinya, selfexpectation dimana siswa merasakan cemas serta merasa tidak puas saat tidak dapat memenuhi harapan atau standar-standar yang ditetapkan oleh dirinya sendiri, dan despondency yang mencakup perasaan tidak yakin atau kurang yakin serta merasakan banyak persoalan yang dialami saat mengikuti pembelajaran di sekolah. 


\section{Alat Ukur \\ Mindfulness}

Menggunakan alat ukur Child and Adolescent Mindfulness Measure (CAMM) yang disusun oleh Baer, et al (2011) dan telah diterjemahkan ke dalam Bahasa Indonesia di Balai Bahasa UPI dengan mempergunakan teknik-teknik standar penerjemahan oleh Rizka Aulia dengan 10 item valid dan nilai alpha cronbach's 0.659 (Aulia, 2019). Alat ukur ini terdiri dari 10 item dimana responden menilai seberapa sering setiap item sesuai dengan keadaan mereka dengan menggunakan 5 point skala yakni 0 (Tidak Pernah), 1 (Jarang), 2 (Kadang-Kadang), 3 (Sering), 4 (Selalu). Item-item pada CAMM diadaptasi dari Kentucky Inventory of Mindfulness Skill.

\section{Stres Akademik}

Menggunakan Educational Stress Scale for Adolescents yang dikembangkan Sun, et al (2011) (Sun, et al, 2011) dan telah diadaptasi dan diterjemahkan ke dalam Bahasa Indonesia oleh Elya Indriani (2020) dan dibantu oleh penerjemah yang berpengalaman. Dengan didapatkan hasil reliabilitas sebesar 0.845 dan keseluruhan item digunakan (Indriani, 2020). Alat ukur ini terdiri dari 16 item yang terbagi dalam 5 aspek yaitu pressure from study, workload, worry about grades, self-expectation, despondency. Pada alat ukur ini terdapat 4 pilihan jawaban yakni 1 (sangat tidak setuju), 2 (tidak setuju), 3 (setuju), 4 (sangat setuju).

\section{Desain Penelitian}

Desain penelitian yang digunakan dalam penelitian ini yaitu kuantitatif dengan menggunakan metode kausalitas, metode ini bertujuan untuk mengetahui dan menyelidiki hubungan pengaruh atau hubungan sebab dan akibat serta melibatkan satu atau lebih variabel independen dan hubungannya dengan satu atau beberapa variabel dependen.

\section{Populasi dan Sampel}

Populasi dalam penelitian ini adalah siswa-siswi SMAN X Cianjur kelas X, XI, dan XII yang mengikuti pembelajaran daring berjumlah 1.163 siswa. Sampel penelitian berjumlah 298 siswa dengan teknik sampling menggunakan proportionate stratified random sampling.

\section{Hasil Penelitian dan Pembahasan}

Berikut adalah hasil penelitian mengenai pengaruh mindfulness terhadap stres akademik pada siswa SMAN X Cianjur di masa pandemi Covid-19, yang diuji menggunakan teknik analisis regresi linear sederhana.

Tabel 1. Hasil uji regresi linear sederhana

\begin{tabular}{lccccc}
\hline $\begin{array}{c}\text { Dependent } \\
\text { Variable }\end{array}$ & $B$ & $S E$ & $\beta$ & $\mathrm{t}$ & $\mathrm{Sig}$ \\
\hline Stres & & & & & \\
Akademik & $\mathbf{6 4 . 1 9 2}$ & 1.374 & & 46.726 & .000 \\
& & & & & \\
& $\mathbf{- 1 . 0 2 5}$ & .063 & -.687 & -16.263 & .000
\end{tabular}

Dari hasil regresi pada tabel 3.1, koefesien regresi dalam penelitian ini yaitu -1.025 , menyatakan bahwa jika variabel mindfulness (X) meningkat sebesar 1\% dan konstanta adalah 0 , maka tingginya stres akademik bagi siswa SMAN X Cianjur menurun sebesar 1.025. Hal tersebut menunjukkan bahwa koefisien regresi tersebut bernilai negatif, sehingga dapat dikatakan bahwa arah pengaruh variabel mindfulness dan stres akademik adalah negatif. Artinya yaitu apabila semakin tinggi nilai mindfulness maka akan menurunkan nilai stres akademik, begitupun sebaliknya apabila semakin rendah nilai mindfulness maka akan meningkatkan nilai stres akademik siswa. Sehingga hipotesis dalam penelitian, yaitu ketika siswa memiliki mindfulness yang rendah, maka stres akademik yang dialami siswa akan tinggi dapat diterima.

Hal ini juga sesuai dengan hasil penelitian yang dilakukan oleh Brown, et al. 
mengenai efek mindfulness terhadap persepsi kejadian-kejadian yang membuat stres atau stresor pada individu. Berdasarkan hasil tersebut, apabila semakin mindful individu maka semakin tidak berbahaya penilaiannya terhadap stres (Brown, et al, 2008). Selain itu sejalan juga dengan manfaat dari mindfulness itu sendiri berdasarkan dari kutipan buku Introduction to Mindfulness, dimana secara umum mindfulness memiliki manfaat yakni lebih efektif untuk menanggapi segala situasi yang sulit dan kompleks, lebih tenang dan damai, bermanfaat untuk meningkatkan fokus dan konsentrasi pikiran, serta salah satunya dapat mengurangi dampak buruk dan pengaruh pikiran serta perasaan stres (Amory, 2013 dalam Aulia, 2019).

Tabel 2. Hasil uji determinasi

\begin{tabular}{lcccc}
\hline $\begin{array}{c}\text { Dependent } \\
\text { Variable }\end{array}$ & $\mathrm{R}$ & $\mathrm{R}^{2}$ & $\begin{array}{c}\text { Adjusted } \\
R^{2}\end{array}$ & $\begin{array}{c}\text { Std. Error of the } \\
\text { Estimate }\end{array}$ \\
\hline Stres & & & & \\
Akademik & $.687^{\mathrm{a}}$ & $\mathbf{. 4 7 2}$ & .470 & 7.11313 \\
\hline
\end{tabular}

a. Predictors: (Constant), Mindfulness

Berdasarkan hasil pada tabel 3.2, dapat diketahui koefisien determinansi $\left(R_{\text {Square }}\right)$ adalah sebesar 0.472 , artinya pengaruh mindfulness terhadap stres akademik sebesar $47.2 \%$ sedangkan sisanya sebesar $52.8 \%$ dipengaruhi variabel lain yang tidak masuk dalam penelitian.

Pada dasarnya ditemukan pernyataan bahwa Ketika seorang siswa dalam keadaan yang mindful, mereka dapat bekerja pada sifat pencapaian belajar yang lebih fokus, lebih terlibat dan menjadi lebih berdamai dengan keadaan yang tidak menyenangkan dan menimbulkan stres (Napoli, et al, 2005). Menurut Gardner dan Grose (2015) juga mengatakan bahwa mindfulness merupakan cara pencegahan tumbuhnya stres, konflik dan kekacauan dalam lingkup pendidikan.

Akan tetapi berdasarkan hasil penelitian serta wawancara yang didapatkan menunjukkan bahwa siswa tidak bisa fokus dengan baik pada saat pembelajaran jarak jauh berlangsung, sehingga siswa tidak secara maksimal melakukan beberapa kegiatan dengan penuh perhatian, siswa juga masih menilai atau menganggap bahwa pandemi ini menghambat mereka, dimana hal tersebut mengartikan bahwa siswa berada dalam keadaan mindfulness yang rendah. Jika siswa tidak sepenuhnya menerapkan mindfulness, siswa dapat mengalami masalah dalam melihat, mengamati, serta menilai permasalahan yang mereka hadapi. KabatZinn (2005) menjelaskan bahwa hal tersebut dapat membuat seseorang kesulitan dalam mengelola berbagai peristiwa yang dialami, sehingga dapat menyebabkan tekanan akademik yang tinggi.

Tabel 3.Hasil perhitungan mindfulness dan stres akademik

\begin{tabular}{ccc}
\hline Variabel & Rendah & Tinggi \\
\hline Mindfulness & $62 \%$ & $38 \%$ \\
Stres Akademik & $26.5 \%$ & $73.5 \%$ \\
\hline
\end{tabular}

Dari hasil tabel 3.3, diperoleh bahwa terdapat 186 atau sebesar $62 \%$ siswa yang memiliki mindfulness kategori rendah, serta diperoleh bahwa terdapat 219 atau sebesar $73.5 \%$ siswa yang memiliki stres akademik kategori tinggi.

Sehingga dari hasil tersebut juga diartikan bahwa sebagian responden mengalami kesulitan untuk selalu sadar atau mengalami kesulitan untuk selalu menaruh penuh perhatian dalam melakukan berbagai kegiatan sehari-hari khususnya ketika mengikuti pembelajaran jarak jauh dan disertai dengan kesulitan untuk melakukan tindakan non-evaluatif sewaktu melakukan berbagai kegiatan ketika mengikuti pembelajaran jarak jauh, dengan kesulitan itu 
akibatnya mereka menghadapi atau menangani stimulus-stimulus seperti tantangan serta tuntutan akademik secara tidak efektif sehingga memunculkan ketegangan, perasaan tidak nyaman yang merupakan indikasi dari nilai stres akademik yang tinggi, yang dimunculkan dari beban kerja atau tugas, kekhawatiran terhadap nilai di sekolah, harapan yang tinggi dan juga keputusasaan, dimana hal-hal tersebut merupakan aspek-aspek dari stres akademik (Sun, et al, 2011).

\section{Kesimpulan}

Berdasarkan analisis data dan pembahasan yang telah dipaparkan pada bab sebelumnya, peneliti membuat kesimpulan mengenai penelitian ini sebagai berikut:

Dari hasil penelitian yang telah diperoleh, didapatkan bahwa mindfulness pada siswa SMAN X Cianjur di masa pandemi Covid-19 dalam kategori yang rendah yaitu sebanyak 186 (62\%) siswa.

Dari hasil penelitian yang telah diperoleh, didapatkan bahwa stres akademik pada siswa SMAN X Cianjur di masa pandemi Covid-19 dalam kategori stres akademik yang tinggi yaitu sebanyak $219(73.5 \%)$ siswa. Sehingga hal ini menunjukkan siswa di SMA ini mengalami stres akademik yang tinggi di tengah keadaan pandemi Covid-19.

Terdapat pengaruh antara mindfulness terhadap stres akademik pada siswa SMAN X Cianjur di masa pandemi Covid-19. Dilihat dari hasil penelitian menunjukkan bahwa jika mindfulness yang rendah maka akan menyebabkan stres akademik yang tinggi. Mindfulness mempengaruhi stres akademik sebesar $47.2 \%$ sedangkan sisanya sebesar $52.8 \%$ dipengaruhi variabel lain yang tidak masuk dalam penelitian.

\section{Acknowledge}

Penulis menyadari bahwa dalam proses penulisan penelitian ini tidak sedikit hambatan yang harus dilalui. Maka dari itu dalam proses penulisan penelitian ini tentunya tidak lepas dari bantuan dari berbagai pihak. Sehingga, penulis mengucapkan terima kasih banyak kepada pembimbing yaitu Ibu Makmuroh Sri Rahayu, Dra, M.Si, Psikolog dan Teh Andhita Nurul Khasanah, S.Psi, M.Psi, Psikolog yang telah membimbing serta memberikan arahan dan ilmunya untuk kelancaran pengerjaan penelitian. Tidak lupa penulis juga mengucapkan terima kasih banyak kepada seluruh responden serta seluruh pihak yang terlibat dalam penelitian ini.

\section{Daftar Pustaka}

[1] Ananda, S. S. D., \& Apsari, N. C. (2020). Mengatasi Stres Pada Remaja Saat Pandemi Covid-19 dengan Teknik Self Talk. Prosiding Penelitian dan Pengabdian kepada Masyarakat, 7(2), 248-256.

[2] Ang, R. P., \& Huan, V. S. (2006). Academic Expectations Stres Inventory: Development, factor analysis, reliability, and validity. Educational and Psychological Measurement, 66(3), 522-539.

[3] Aulia, Rizka. (2019). Pengaruh Mindfulness Terhadap Adolescent Well-Being Pada Remaja di Pondok Pesantres Yatim Dhuafa Al-Kasyaf. Skripsi. Fakultas Psikologi Universitas Islam Bandung.

[4]Baer, R. A., Smith, G. T., Hopkins, J., Krietemeyer, J., \& Toney, L. (2006). Using self-report assessment methods to explore facets of mindfulness. Assessment, 13(1),27-45. doi: $10.1177 / 1073191105283504$

[5]Baer, R. A., Smith, G. T., \& Greco, L. A. (2011). Assessing Mindfulness in Children and Adolescents: Development and Validation of the Child and Adolescent Mindfulness Measure (CAMM). Retrieved from American Psychological Association, Psychological Assessment. 23(3), 606-614. doi: 10.1037/a0022819.

[6] Barseli, M., Ifdil, I., \& Nikmarijal, N. (2017). Konsep stres akademik siswa. Jurnal konseling dan pendidikan, 5(3), 143-148.

[7] Barseli, M., Ifdil, I., Mudjiran, M., Efendi, Z. M., \& Zola, N. (2020). Pengembangan modul 
bimbingan dan konseling untuk pengelolaan stres akademik siswa. Jurnal Konseling Dan Pendidikan, 8(2), 72-78.

[8] Brown, K. W., Ryan, R. M., \& Weinstein, N. (2008). A Multi Method Examinationof the Effects of Mindfulness on Stres Atribution Coping, and Emotional Well Being. Journal of Research in Personality, 43. 374-385.

[9]Elizabeth, M. (2017). The relationship between mindfulness and stress among college students. Rowan University.

[10] Fegert, J. M., Vitiello, B., Plener, P. L., \& Clemens, V. (2020). Challenges and burden of the Coronavirus 2019 (COVID-19) pandemic for child and adolescent mental health: a narrative review to highlight clinical and research needs in the acute phase and the long return to normality. Child and adolescent psychiatry and mental health, 14, 20. https://doi.org/10.1186/s13034-020-00329-3.

[11] Gardner, P., \& Grose, J. (2015). Mindfulness in the academy-transforming our work and ourselves 'one moment at a time'. Collected Essays on Learning and Teaching, 8, $35-46$.

[12] Hidayat, O., \& Fourianalistyawati, E. (2017). Peranan Mindfulness Terhadap Stres Akademis Pada Mahasiswa Tahun Pertama. Jurnal Psikogenesis, 5(1). https://doi.org/10.24854/jps.v5i1.494.

[13] Indriani, Elya. (2020). Pengaruh Dukungan Sosial Terhadap Stres Akademik Pada Siswa SMA di Surabaya. Skripsi. Fakultas Psikologi Universitas Airlangga.

[14] Jim, H. (2017 May 11). Study: MetroWest teens feeling more stres. Metrowest Daily News. Retrieved from https://www.metrowestdailynews.com.

[15] Kabat-Zinn, J. (2005). Full Catastrophe Living Using the Wisdom of Your Body and Mind to Faces Stress, Pain, and Illness. New York: A Division of Random House Inc.

[16] Martin, L., \& Kagee, A. (2011). Lifetime and HIV-related PTSD among persons recently diagnosed with HIV. AIDS and Behavior, 15(1), 125-131.

[17] Muslim, M. (2020). Manajemen Stress Pada Masa Pandemi Covid-19. ESENSI: Jurnal Manajemen Bisnis, 23(2), 192-201.

[18] Napoli, M., Krech, P. R., \& Holley, L. C. (2005). Mindfulness training for elementary school students: The attention academy. Journal of applied school psychology, 21(1), 99-125.

[19] Qurrotu'ain, Q. (2019). Perbedaan stres akademik berdasarkan latar belakang pendidikan pada SMA Negeri 3 Samarinda dan SMAIT Granada Samarinda. Psikoborneo, 7(3), 622-632.

[20] Rahardjo, W., Qomariyah, N., Mulyani, I., \& Andriani, I. (2020). Social Media Fatique pada Mahasiswa di Masa Pandemi Covid-19: Peran Neurotisisme, Kelebihan Informasi, Invasi Of Live, Kecemasan, dan Jenis Kelamin. Psikologi Sosial, 18(59), 12.

[21] Reger, M. A., Stanley, I. H., \& Joiner, T. E. (2020). Suicide Mortality and Coronavirus Disease 2019-A Perfect Storm?. JAMA psychiatry, 77(11), 1093-1094. https://doi.org/10.1001/jamapsychiatry.2020.1060

[22] Santrock, J. W. (2011). Perkembangan Masa-Hidup Edition Jilid 1. Jakarta: Erlangga.

[23] Sarmin, S. (2017). Konselor Sebaya: Pemberdayaan Teman Sebaya dalam Sekolah Guna Menanggulangi Pengaruh Negatif Lingkungan. Briliant: Jurnal Riset dan Konseptual, 2(1), 102-112.

[24] Singh , K., Junnarkar, M., \& Kaur , J. (2016). Measures of positive psychology development and validation. India : Springer India. doi:10.1007/978-81-322-3631-3.

[25] Sun, J., Dunne, M. P., \& Hou, X.-Y. (2011). Educational stres scale for adolescents : development, validity, and reliability with Chinese students. Journal of Psychoeducational Assessment, 29(6). doi: 10.1177/0734282910394976.

[26] Taufik, T., Ifdil, I., \& Ardi, Z. (2013). Kondisi Stres Akademik Siswa SMA Negeri di Kota Padang. Jurnal Konseling dan Pendidikan, 1(2), 143-150. 
https://doi.org/10.29210/12200.

[27] Utami, A. T., Khasanah, A. N., Mubarak, A., \& Sartika, S. (2020). Mindful Parenting: Study on Parents of Preschool Children.https://doi.org/10.2991/assehr.k.200225.080.

[28] Waskito, P., Loekmono, J. L., \& Dwikurnaningsih, Y. (2018). Hubungan antara mindfulness dengan kepuasan hidup mahasiswa bimbingan dan konseling. Jurnal Kajian Bimbingan dan Konseling, 3(3), 99-107.

[29] Zhang, C., Ye, M., Fu, Y., Yang, M., Luo, F., Yuan, J., \& Tao, Q. (2020). The Psychological Impact of the COVID-19 Pandemic on Teenagers in China. Journal of Adolescent Health, 67(January), 747-755. doi: 10.1016/j.jadohealth.2020.08.026 